\title{
Study of Crop Evapotranspiration and Irrigation Scheduling of Different Crops Using Cropwat Model in Waghodia Region, India
}

\author{
Khose Suyog Balasaheb ${ }^{1}$ and Sudarsan Biswal ${ }^{2 *}$ \\ ${ }^{1}$ Former Graduate Student, College of Agricultural Engineering and Technology, \\ VNMKV, Parbhani, Maharashtra, India \\ $2^{*}$ Former Post-Graduate Student, Water Resources Engineering, Veer Surendra Sai \\ University of Technology (VSSUT), Burla, Odisha, India \\ *Corresponding author
}

\section{A B S T R A C T}

Keywords

CROPWAT 8.0,

Crop water

requirement,

Irrigation

scheduling,

Reference

evapotranspiration

Article Info

Accepted:

26 April 2020

Available Online:

10 May 2020
To control the overexploitation of accessible water resources, it has become essential to define proper strategies for planning, development, and management of water resources. Proper modification in traditional irrigation practices helps improve water use efficiency. CROPWAT is an FAO suggested model for proper management of irrigation. CROPWAT model integrates with soil, crop, and climate information for estimation of reference evapotranspiration $\left(\mathrm{ET}_{0}\right)$, crop evapotranspiration $\left(\mathrm{ET}_{\mathrm{c}}\right)$, crop water requirement $(\mathrm{CWR})$ and irrigation water requirements (IWR).It also develops and manages the irrigation scheduling. The average annual rainfall of Waghodia region was $907 \mathrm{~mm}$ of, and out of this, $527.6 \mathrm{~mm}$ was useful for crop growth and development. The CWR for Waghodia Region is estimated as $241.3 \mathrm{~mm}, 480.9 \mathrm{~mm}$, and $339.3 \mathrm{~mm}$ and irrigation requirement as $188.8 \mathrm{~mm}, 343.3 \mathrm{~mm}$, and $333.9 \mathrm{~mm}$ for sorghum, rice, and wheat crop, respectively. CROPWAT 8.0 model can efficiently and effectively calculate the evapotranspiration and net requirements of irrigation water. The CROPWAT 8.0 Model can play an important role in the irrigation management practices as well as irrigation scheduling of crops over manual irrigation practicing using different water supply systems.

\section{Introduction}

The availability of freshwater water resources for agriculture is an alarming issue with increasing the demand of water for different sectors (IWMI, 2010). According to United Nations report (2019), the world population in
2050, will be predicted to peak at 9.7 billion. To attain the demand of the growing populace of the world, proper utilization of the available water resources is the main challenge for researchers. Among all freshwater using sectors around the world, agriculture contributes to an average of 70 
percent (Alexandratos and Bruinsma, 2012). Since, water is highly used by agriculture, it is essential to improve agriculture water management practices and adopt some new water-saving measures for agriculture purposes. The principal reason for the irrigation is to fulfill the demand of water to meet required $\mathrm{ET}_{\mathrm{c}}$ when precipitation is deficient for proper growth of crop till the final growth of crop. The irrigation system incorporates the utilization of the exact quantity of water at the correct time to crop for development of plant. Therefore, estimation of CWR and proper irrigation scheduling is required for irrigation water planning and management purpose (Ewaid et al., 2019).

Wheat (Triticum aestivum L.) is one of the most significant grain crops on the earth. In the context of nutrients, wheat is a major source for approximately 40 percent of the world's population. It provides around 20 percent of the total food calories for humans (Giraldo, 2019). According to State Agriculture Plan and State Infrastructure Development Plan (SAP and SIDP) (2017-18 to 2019-20), Gujrat, wheat is grown on 0.9 $1.6 \mathrm{M}$ ha that comprises $23 \%$ of the land used for cereals. The average wheat production and productivity in Gujarat were 38.12 lakh tonnes (2011- 12 to 2016-17) and 29.96 and $30.16 \mathrm{q} / \mathrm{ha}$, respectively. Maximization of wheat production can be achieved through appropriate agronomic practices. Wheat required $278-373 \mathrm{~mm}$ of water through out season (Singh et al., 2014). Proper irrigation practices are essential for proper management of wheat crop. For proper management, it is required to determine the CWR and irrigation scheduling of wheat.

Sorghum (Sorghum bicolour L. Moench) is the third most grain used in the world to feed the human population. Water stress can significantly affect sorghum yield potential. It is essential to monitor soil moisture and apply irrigation when soil moisture depleted (Mundia et al., 2019) for maintaining yield potential. Also, Rice has mostly consumed food for most of the world. Cultivation of rice through conventional methods takes about 50-300 cm of water (Bouman and Tuong, 2001), from which runoff and seepage loss is almost 50 - 80 percent. Shah et al., (2015) reported that about 40-60 percent of water used by plants and the rest of the water lost from the field in the form of evapotranspiration, deep percolation, etc. CWR of paddy is estimated as $50.49 \mathrm{~cm}$ for a part of hirakud command area and irrigation scheduling (Biswal and Rath, 2016). So, for all three major crops, the production can be increased by improving the irrigation scheduling method. Increasing crop production with available water resources is the challenge for the coming decades. Therefore, there is a serious need fora modified irrigation scheduling method (Koech et al., 2018). The management of irrigation water involves proper irrigation scheduling (Chitu et al., 2020). Irrigation scheduling includes two aspects: taking the decision to irrigate and executing it through a specific irrigation management approach. The principle irrigation system's decisions are (1) when to start the irrigation event, (2) how much irrigation solution to deliver during the irrigation event (Capraro et al., 2019). Insufficient irrigation or over-irrigation could be responsible for reducing crop yields, quality, and poor nutrient use efficiency (Shah et al., 2015). The irrigation scheduling help farmers to maximize yields and makes maximum use of soil moisture storage through less irrigation. Irrigation scheduling results in increasing crop yields that eventually results in increasing net returns. The CROPWAT model was found as an useful tool for scheduling irrigation under deficit irrigation conditions. 
CROPWAT is one of the models that broadly utilized in the field of irrigation water management all over the world, which is developed by the Land and Water Development Division of the Food Agricultural Organization (FAO). Its primary function is to calculate $\mathrm{ET}_{0}$, crop water, and irrigation water requirements, develop and manage proper scheduling of irrigation water, and design irrigation schemes. It allows the development of guidance for revise irrigation exercise, proper irrigation scheduling under different water contribute systems, and the production assessment under different irrigation exercises. CWR of Sorgum is estimated as $187.5 \mathrm{~mm}$ for Waghodia Region, Vadodara district, Gujrat, India (Kumari, 2017). But the estimation of CWR for rice and wheat has not proposed in this paper. Considering this gap, the objective of this study are 1. To determine the crop water requirement and irrigation scheduling for Wheat, Sorghum, and Rice crop using CROPWAT 8.0 software, 2. To determine Reference Evapotranspiration and the effect of atmospheric parameters on it.

\section{Materials and Methods}

\section{Study area}

The study was conducted in Waghodia Region, Vadodara district, Gujarat, India (Latitude $22^{\circ} 30^{\prime} \mathrm{N}$ and Longitude $73^{\circ} 38^{\prime} \mathrm{E}$ ) (Figure 1). The climate of the place is under the tropical region. The average annual rainfall of the study region was $96.4 \mathrm{~cm}$. The average temperature is $27.3^{\circ} \mathrm{C}$. The average annual wind speed, humidity, and radiation were $2 \mathrm{~km} /$ day, $65 \%$, and $18.1 \mathrm{MJ} / \mathrm{m}^{2} /$ day, respectively. Entire Gujarat is divided into various Agro-climatic zones, and the Vadodara district is covered in Agro climatic zones-3. The study area is under the Vadodara region and its command area located in Middle Gujarat.

\section{Data collection}

\section{Meteorological data}

The Meteorological data is taken from the literature published by Kumari, 2017. The wind speed, temperature (maximum and minimum), sunshine hours, relative humidity, and rainfall data (monthly) are considered. Reference evapotranspiration $\left(\mathrm{ET}_{0}\right)$ is also estimated using CROPWAT.

\section{Crop data}

The required data such as crop name, planting date, rooting depth of crop at different growing stages, critical depletion, crop coefficient, yield response factor, and harvesting data (Allen et al., 1998) for sorghum, rice, and wheat crops are collected from FAO 56 manual (Table 1). Depletion factor, Crop Coefficient for Sorghum, Rice, and Wheat are also measured.

\section{Soil data}

Waghodia region has black clay type soil. The software needs some general soil data that has been obtained from the FAO 56 manual (Table 2).

\section{Model description and setup}

Land and Water Development Division of FAO, Italy, with coordination to Irrigation and Development Studies of Southampton, UK, and National Water Research Centre, Egypt developed a decision support system for windows called CROPWAT 8.0. It calculates CWR as well as water requirements for irrigation based on the soil, crop and climatic data. It also develops the irrigation schedule under different water supply systems and schemes of water supply for different cropping patterns. It can be used under rainfed as well as irrigated conditions to 
assess the crop performance. In CROPWAT 8.0 model $\mathrm{ET}_{0}$ is estimated using the FAO Penman-Monteith method (1992). Estimated $\mathrm{ET}_{0}$ is used to estimate crop water and IWR and irrigation scheduling. Estimated IWR using CROPWAT 8.0 is either per week or per month period basis or according to the requirement of cropping pattern for the different growth stages of crop development of the crop in the irrigated region (Memon and Jamsa, 2018). In the schedule module of CROPWAT 8.0, the soil water balance is carried out daily.

\section{Evapotranspiration}

For estimation of reference evapotranspiration in CROPWAT 8.0 model, FAO PenmanMonteith equation is used (Smith et al., 1998; Sentelhas et al., 2010), which described as

$E T_{0}=\frac{0.408 \Delta R_{n}+\gamma\left(\frac{900}{T_{\operatorname{mean}}+278,16}\right) u_{2}\left(e_{s}-e_{a}\right)}{\Delta+\gamma\left(1+0.34 u_{n}\right)}$

Where, $\mathrm{ET}_{0}=$ Reference Evapotranspiration, $\mathrm{R}_{\mathrm{n}}=$ Net solar radiation at the crop surface (MJ/m²/day),

$\mathrm{T}_{\text {mean }}=$ Daily mean maximum and minimum temperatures $\left({ }^{\circ} \mathrm{C}\right)$,

$u_{2}=$ Wind speed at standard $2 \mathrm{~m}$ height $(\mathrm{m} / \mathrm{s})$,

$e_{a}$ Actual vapor pressure $(\mathrm{kPa})$, is the and

$\Delta=$ Slope of vapor pressure curve $\left(\mathrm{kPa} /{ }^{\circ} \mathrm{C}\right)$,

$e_{s}=$ Saturation vapor pressure $(\mathrm{kPa})$,

$\gamma=$ Psychrometric constant $\left(\mathrm{kPa} /{ }^{\circ} \mathrm{C}\right)(=0.054)$.

Crop coefficient $\left(\mathrm{K}_{\mathrm{c}}\right)$ is combined with reference evapotranspiration to calculate crop Evapotranspiration. The $\mathrm{K}_{\mathrm{c}}$ values at three growth stages (i.e. initial, mid, end stage) are directly taken from Allen et al., (1998), Pereira et al., (2015).

$$
E T_{c}=K_{c} \times E T_{0}
$$

\section{Effective rainfall}

The rainfall is the basic input for the determination of CWR. For satisfying CWR, the contribution of rainfall is important, depending upon the location of the study area. Effective rainfall is determined using Soil conservation service formula of USDA in CROPWAT 8.0 model.

For Monthly steps: for P rainfall,

$\mathrm{P}_{\mathrm{eff}}=\mathrm{P}^{*}(125-0.2 * \mathrm{P}) / 125$ for $\mathrm{P}<=250 \mathrm{~mm}$

$\mathrm{P}_{\mathrm{eff}}=125+0.1 * \mathrm{P}$ for $\mathrm{P}>250 \mathrm{~mm}$

Where, $\mathrm{P}_{\text {eff }}=$ Effective rainfall in $\mathrm{mm}$, $\mathrm{P}=$ Total rainfall in $\mathrm{mm}$.

\section{Irrigation scheduling}

Irrigation scheduling helps to decide the precise quantity of the water for proper timely irrigation. Calculated $\mathrm{ET}_{\mathrm{c}}, \mathrm{CWR}$, IWR are used for the development of scheduling of irrigation under different supply of water (Allen et al., 2005).

\section{Results and Discussion}

Crop water requirements and Irrigation scheduling of three crops, i.e., Wheat, Rice, and Sorghum is estimated using CROPWAT.

\section{Reference evapotranspiration}

The values of reference evapotranspiration $\left(\mathrm{ET}_{0}\right)$ are simulated through CROPWAT 8.0 model using the Penman-Monteith equation. Monthly variation of $\mathrm{ET}_{0}$ is estimated using meteorological parameters like temperature, humidity etc. for the Waghodia region (Figure 2). The $\mathrm{ET}_{0}$ is minimum in December and January month, and attained its peak during the month of April-June and further declined 
during the month of July-September. From Figure 1(a), it can be seen that the $\mathrm{ET}_{0}$ is linearly increasing with Maximum temperature as compared to the minimum temperature. Whereas, from figure 1(b) it can be seen that $\mathrm{ET}_{0}$ is inversely proportional to the relative humidity. From figure 1(c) and (d), it can be revealed that the $\mathrm{ET}_{0}$ is directly proportional to the solar radiation and sunshine hours. $\mathrm{ET}_{0}$ is highest $(5.23 \mathrm{~mm} /$ day $)$, and lowest value $(1.9 \mathrm{~mm} /$ day $)$ in May and December, respectively. The rainfall and air temperature have an impact on determination of $\mathrm{ET}_{0}$. In conclusion, solar radiation is a powerful meteorological parameter for the estimation of $\mathrm{ET}_{0}$.

\section{Effective rainfall}

Different method (Fixed percentage, Empirical formula, Dependable rain, and USDA Soil Conservation Service methods) are in CROPWAT 8.0 model for the estimation of the effective rainfall. Rainfall is observed to be zero (Figure 2) in the nonrainy season (month of Oct-May). In the rainy season, the effective rainfall is only $49-87 \%$ of the rainfall due to the losses. $\mathrm{ET}_{0}$ is less in the rainy season and winter season as compared to summer. From Jul, Aug, and Sep month, it is observed that $\mathrm{ET}_{0}$ is varied with effective rainfall. The total average effective rainfall of the Waghodia region is found to be $527.6 \mathrm{~mm}$, which is $58.16 \%$ of the total rainfall occurred. Figure 3 shows the monthly seasonal rainfall, effective monthly rainfall, and reference evapotranspiration for the Waghodia region.

\section{Crop water requirement}

In the present study, evaporative demand is estimated using the Penman-Monteith equation, and it is related to the crop's water use for growing periods. The model is calculated the CWR on a daily basis. Crop water and irrigation requirement of sorghum, rice, and wheat are given in Table 3. The total estimated water requirement for sorghum is found to be $241.3 \mathrm{~mm}$. The required irrigation water is estimated by subtracting the effective rainfall from CWR. For the sorghum crop, it is found to be $188.8 \mathrm{~mm}$ which is nearly equal to the estimated CWR value proposed by Kumari (2017). The CWR data is slightly different from the Kumari (2017) because the transplantation data which we have considered from FAO data. For sorghum, irrigation water is required only in October, November, and December because there is no rainfall throughout these months to satisfy the CWR. For rice, the estimated CWR is 480.9 $\mathrm{mm}$, and the IWR is found to be $343.3 \mathrm{~mm}$. Irrigation is required in June and July for land preparation of rice and in October and November months for its growth. For wheat, IWR and CWR are found to be the same as $333.9 \mathrm{~mm}$. Crop period of wheat is December to April, during which no rainfall occurs. Therefore, CWR is satisfied by irrigation water only. For all the three crops, the highest CWR is found in development and mid-stages and less requirement of water for crop in the initial and late stages.

\section{Irrigation scheduling}

Irrigation is scheduled based on climate data, including rainfall, humidity, sunshine hour, temperature and sowing date, soil characteristics, etc. using the CROPWAT 8.0 software. Irrigation Scheduling is calculated by maintaining critical depletion at $100 \%$, restore the moisture content of soil to $100 \%$ field capacity. Seventy percent of irrigation efficiency is considered. Irrigation scheduling is estimated for three crops in Waghodia region.

\section{Sorghum}

Based on the study of daily rainfall and evapotranspiration data, irrigation is not required at initial and development stage, as 
the effective rainfall is more than the $\mathrm{ET}_{\mathrm{c}}$. The crop sustained up to 63 days from sowing due to rainfall. After that first irrigation of 79.3 $\mathrm{mm}$ should be given to protect the crop from water-stressed conditions. Furthermore, the subsequent irrigation may be given after 93 days with $78.4 \mathrm{~mm}$ of net irrigation. Considering an efficiency of $70 \%$ during each irrigation supplied by flooding with an unavoidable loss due to various causes, the gross irrigation requirement during each irrigation will be $113.2 \mathrm{~mm}, 112.1 \mathrm{~mm}$. Irrigation scheduling of sorghum has been presented in Table 4, and the respective pictorial representation is shown in Figure 4.

\section{Rice}

Based on the study of daily rainfall and evapotranspiration data, it is observed that during initial, development, and mid-stage, there was no need of irrigation, because of effective rainfall was more than $\mathrm{ET}_{\mathrm{c}}$. However, before planting, there was a need for irrigation for land preparation, i.e., for prepuddling and puddling, which is 19 and 4 days before plating with $96.6 \mathrm{~mm}$ and 84.9 $\mathrm{mm}$ irrigation, respectively. As this irrigation water is used for preparation and puddling purposes, the losses are neglected. Then subsequent irrigations should be given after 89, 104, and 121 days after sowing with 99.2 $\mathrm{mm}, 96.7 \mathrm{~mm}$, and $95.4 \mathrm{~mm}$ of net irrigation, respectively. The gross irrigation for rice is $502.8 \mathrm{~mm}$. Irrigation scheduling of rice presented in Table 5, and the respective pictorial representation is shown in Figure 5.

Table.1 Soil data for the study area

\begin{tabular}{|c|c|c|c|}
\hline Crop & Sorghum & Rice & Wheat \\
\hline Sowing Date & 20 Aug & $15 \mathrm{Jul}$ & $31 \mathrm{Dec}$ \\
\hline Harvesting Date & $22 \mathrm{Dec}$ & $21 \mathrm{Nov}$ & 29 April \\
\hline \multicolumn{4}{|c|}{ Crop Growing Stages (Day) } \\
\hline Initial stage & 20 & 30 & 15 \\
\hline Development Stage & 35 & 20 & 25 \\
\hline Mid Stage & 40 & 30 & 50 \\
\hline Late stage & 30 & 50 & 30 \\
\hline \multicolumn{4}{|c|}{ Ranges of Maximum Effective Rotting Depth } \\
\hline Max. Root Depth (m) & $0.5-0.6$ & $0.5-0.6$ & $1.5-1.8$ \\
\hline \multicolumn{4}{|c|}{ Soil water Depletion Fraction for No Stress } \\
\hline Depletion Fraction (P) & 0.55 & 0.5 & 0.55 \\
\hline \multicolumn{4}{|c|}{ Single Crop Coefficient $K_{c}$} \\
\hline $\mathbf{K}_{\mathbf{c}}$ (initial) & 0.30 & 0.5 & 0.7 \\
\hline $\mathbf{K}_{\mathbf{c}}(\mathbf{m i d})$ & 1.0 & 1.05 & 1.15 \\
\hline$K_{c}($ end $)$ & 0.55 & 0.70 & 0.25 \\
\hline \multicolumn{4}{|c|}{ Maximum Plant Heights } \\
\hline Crop Height & 1.2 & 1.0 & 1.0 \\
\hline
\end{tabular}


Table.2 Soil data for the study area

\begin{tabular}{|l|l|}
\hline \multicolumn{2}{|c|}{ Soil Type: Black Clay Soil } \\
\hline Total available soil moisture (FC - WP) & $150.0 \mathrm{~mm} / \mathrm{meter}$ \\
\hline Maximum rain infiltration rate & $13 \mathrm{~mm} /$ day \\
\hline Maximum rooting depth & $90 \mathrm{~cm}$ \\
\hline Initial soil moisture depletion (as \% TAM) & $50 \%$ \\
\hline
\end{tabular}

Table.3 Crop water requirement and irrigation requirement of sorghum, rice, and wheat

\begin{tabular}{|c|c|c|c|c|c|c|}
\hline \multirow{2}{*}{ Month } & \multicolumn{2}{|c|}{ Sorghum } & \multicolumn{2}{|c|}{ Rice } & \multicolumn{2}{c|}{ Wheat } \\
\cline { 2 - 7 } & $\begin{array}{c}\text { Etc } \\
(\mathrm{mm} / \mathrm{month})\end{array}$ & $\begin{array}{c}\text { Irri. Req. } \\
(\mathrm{mm} / \mathrm{month})\end{array}$ & $\begin{array}{c}\text { Etc } \\
(\mathrm{mm} / \mathrm{month})\end{array}$ & $\begin{array}{c}\text { Irri. Req. } \\
(\mathrm{mm} / \mathrm{month})\end{array}$ & $\begin{array}{c}\text { Etc } \\
(\mathrm{mm} / \mathrm{month})\end{array}$ & $\begin{array}{c}\text { Irri. Req. } \\
(\mathrm{mm} / \mathrm{month})\end{array}$ \\
\hline Jan & 0 & 0 & 0 & 0 & 55.3 & 55.3 \\
\hline Feb & 0 & 0 & 0 & 0 & 81.2 & 81.2 \\
\hline Mar & 0 & 0 & 0 & 0 & 115.2 & 115.2 \\
\hline Apr & 0 & 0 & 0 & 0 & 80.8 & 80.8 \\
\hline May & 0 & 0 & 0 & 0 & 0 & 0 \\
\hline Jun & 0 & 0 & 22.5 & 102.6 & 0 & 0 \\
\hline Jul & 0 & 0 & 99.4 & 84.9 & 0 & 0 \\
\hline Aug & 10.9 & 0.9 & 101.8 & 0 & 0 & 0 \\
\hline Sep & 42.4 & 0 & 101.3 & 0 & 0 & 0 \\
\hline Oct & 92.3 & 92.2 & 107.1 & 107 & 0 & 0 \\
\hline Nov & 68.7 & 68.7 & 48.8 & 48.8 & 0 & 0 \\
\hline Dec & 27 & 27 & 0 & 0 & 1.4 & 1.4 \\
\hline Total & 241.3 & 188.8 & 480.9 & 343.3 & 333.9 & 333.9 \\
\hline
\end{tabular}

Table 4.Irrigation scheduling of sorghum

\begin{tabular}{|l|l|l|l|l|c|c|}
\hline $\begin{array}{l}\text { Number of } \\
\text { Irrigation }\end{array}$ & Day & $\begin{array}{l}\text { Days after } \\
\text { Planting }\end{array}$ & Stage & $\begin{array}{l}\text { Depletion } \\
(\mathbf{\%})\end{array}$ & $\begin{array}{c}\text { Net } \\
\text { Irrigation } \\
(\mathbf{m m})\end{array}$ & $\begin{array}{c}\text { Gross } \\
\text { Irrigation } \\
\text { (mm) }\end{array}$ \\
\hline 1st & $21-$ Oct & 63 & Mid & 59 & 79.3 & 113.2 \\
\hline 2nd & $20-$ Nov & 93 & Mid & 58 & 78.4 & 112.1 \\
\hline End & 22-Dec & End & End & 34 & & \\
\hline
\end{tabular}


Table.5 Irrigation scheduling of rice

\begin{tabular}{|c|c|c|c|c|c|c|c|}
\hline $\begin{array}{l}\text { Number } \\
\text { of } \\
\text { Irrigation }\end{array}$ & Day & $\begin{array}{c}\text { Day } \\
\text { after } \\
\text { Planting }\end{array}$ & Stage & $\begin{array}{c}\text { Depletion } \\
\text { SM }\end{array}$ & $\begin{array}{c}\text { Net } \\
\text { Irrigation } \\
(\mathbf{m m})\end{array}$ & Loss & $\begin{array}{c}\text { Gross } \\
\text { Irrigation } \\
(\mathbf{m m})\end{array}$ \\
\hline 1st & 25-Jun & -19 & Pre-Puddling & 39 & 96.6 & 0 & 96.6 \\
\hline 2nd & 10-Jul & -4 & Puddling & 0 & 84.9 & 0 & 84.9 \\
\hline 3rd & $11-\mathrm{Oct}$ & 89 & End & 0 & 99.2 & 10 & 109.2 \\
\hline 4th & 26-Oct & 104 & End & 0 & 96.7 & 10 & 106.7 \\
\hline 5 th & 12-Nov & 121 & End & 0 & 95.4 & 10 & 105.4 \\
\hline End & 21-Nov & End & End & 0 & 0 & 0 & 0 \\
\hline
\end{tabular}

Table.6 Irrigation scheduling of Wheat

\begin{tabular}{|l|c|c|c|c|c|c|}
\hline $\begin{array}{l}\text { Number } \\
\text { of } \\
\text { Irrigation }\end{array}$ & Day & $\begin{array}{c}\text { Day after } \\
\text { Planting }\end{array}$ & Stage & $\begin{array}{c}\text { Depletion } \\
\mathbf{( \% )}\end{array}$ & $\begin{array}{c}\text { Net } \\
\text { Irrigation } \\
\text { (mm) }\end{array}$ & $\begin{array}{c}\text { Gross } \\
\text { Irrigation } \\
\text { (mm) }\end{array}$ \\
\hline 1st & 01-Jan & 2 & Initial & 57 & 24.1 & 34.5 \\
\hline 2nd & 17-Jan & 18 & Dev & 56 & 45.2 & 64.6 \\
\hline 3rd & 07-Feb & 39 & Dev & 55 & 73.6 & 105.1 \\
\hline 4th & 04-Mar & 64 & Mid & 56 & 76.2 & 108.8 \\
\hline 5th & 25-Mar & 85 & Mid & 57 & 77.2 & 110.3 \\
\hline 6th & 15-Apr & 106 & End & 56 & 75.7 & 108.1 \\
\hline End & 29-Apr & End & End & 21 & & \\
\hline
\end{tabular}

Figure.1 Waghodia region and its location in India

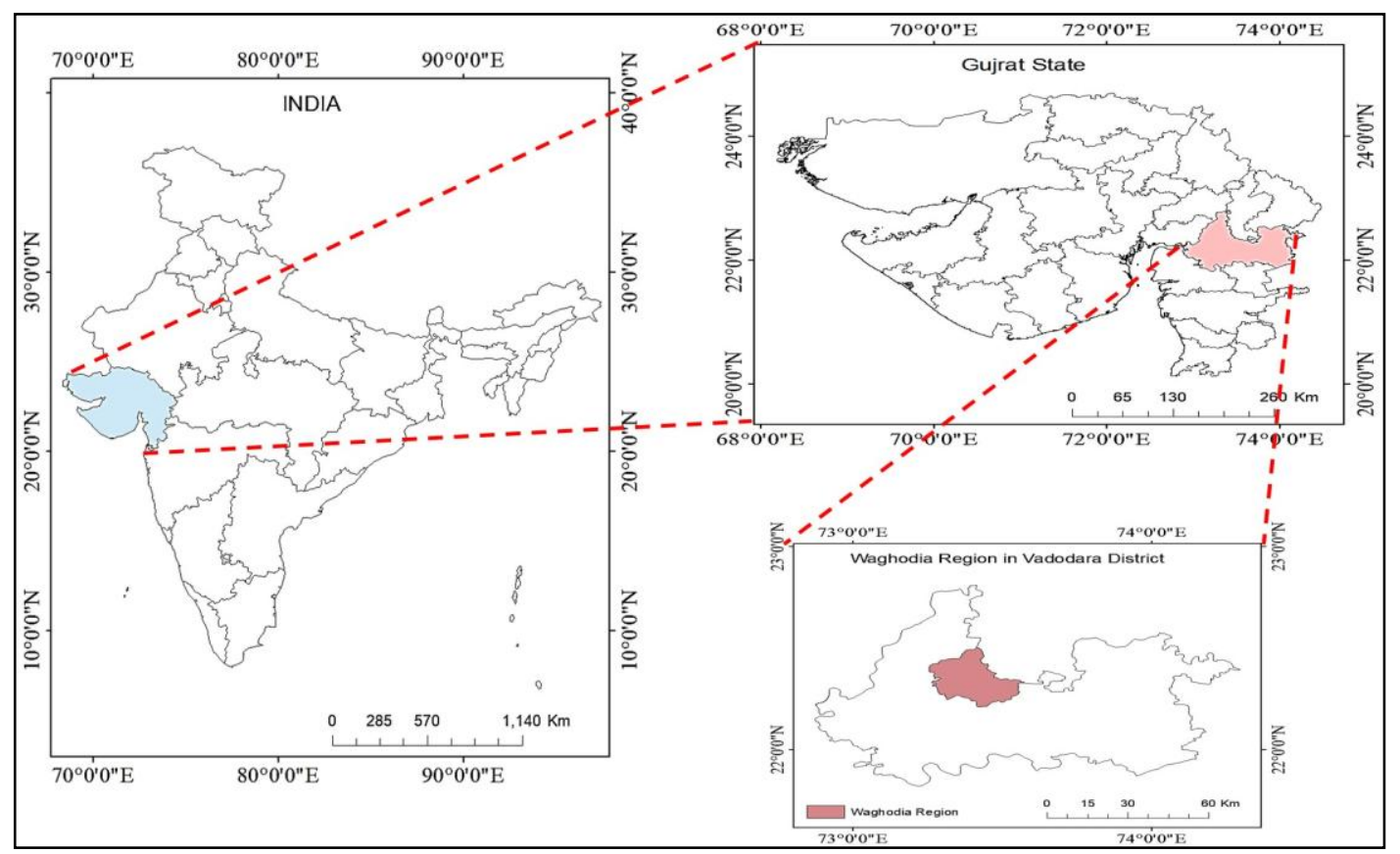


Figure.2 Monthly variation of reference evapotranspiration $\left(\mathrm{ET}_{0}\right)$, with (a) Max and Min Temperature, (b) Humidity, (c) Sunshine Hour, (d) Solar radiation

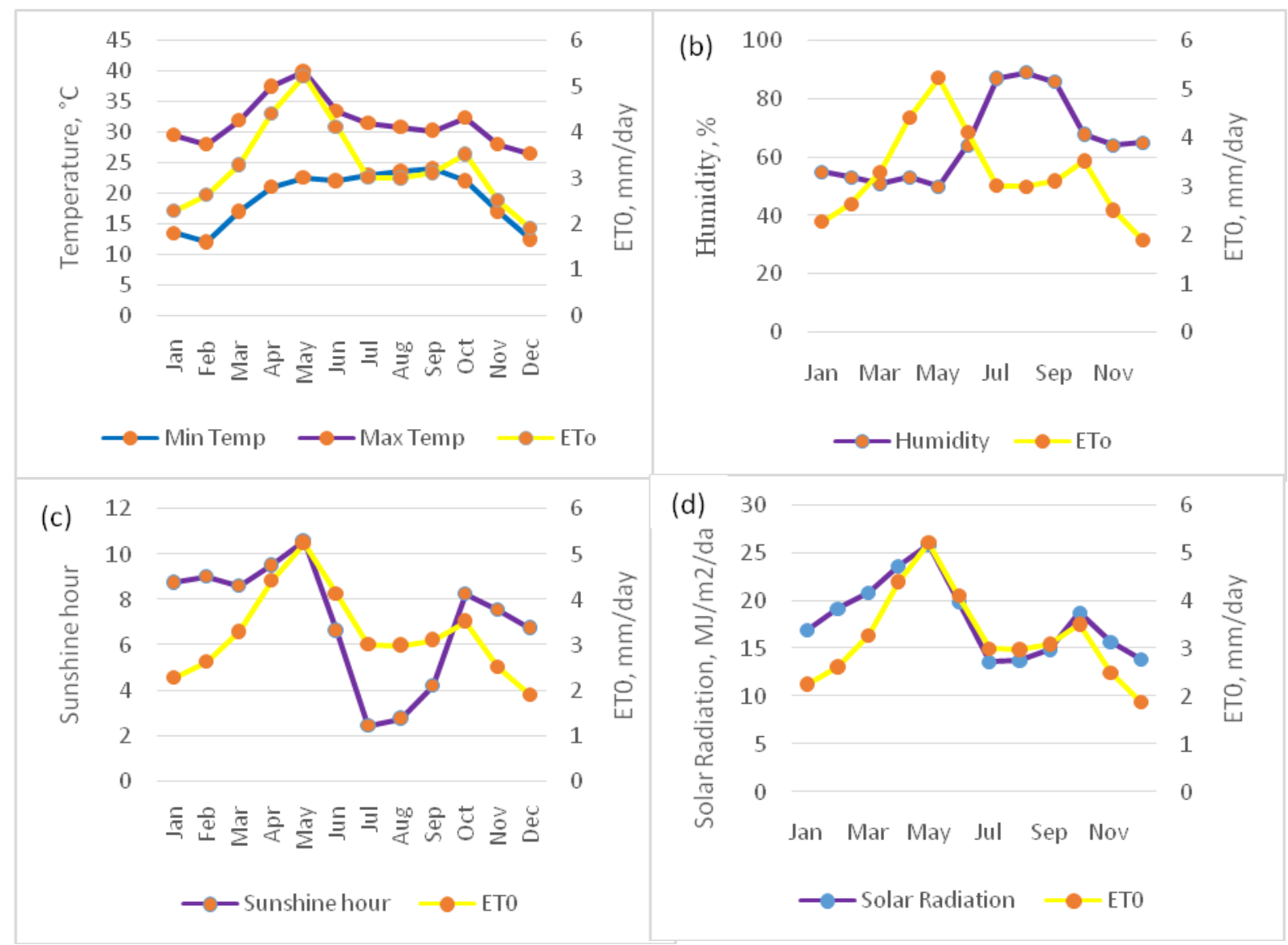

Figure.3 Monthly variation of Reference Evapotranspiration $\left(\mathrm{ET}_{0}\right)$ with rainfall and effective rainfall at Waghodia Region

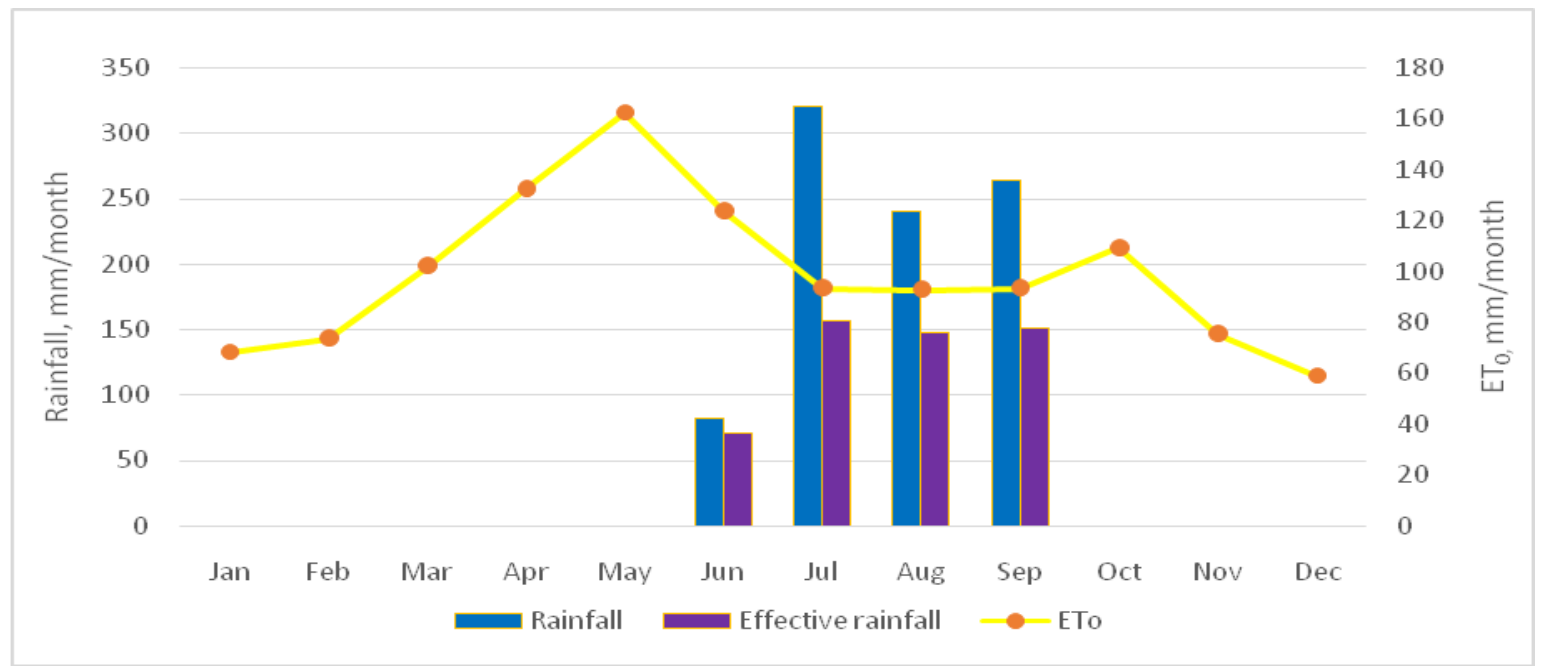


Figure.4 Pictorial representation of irrigation scheduling of sorghum

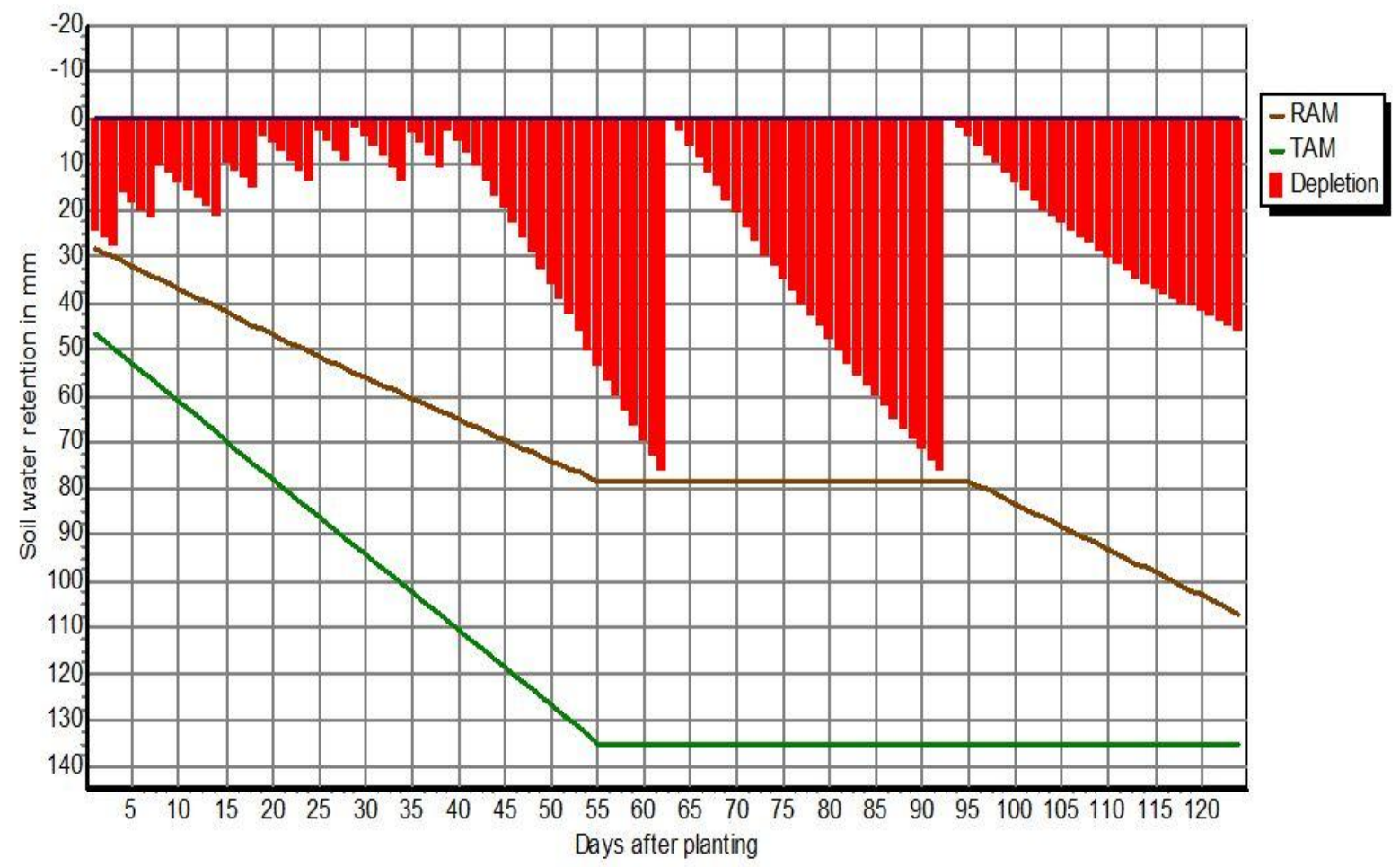

Figure.5 Pictorial representation of Irrigation scheduling of rice (SAT was the depletion of saturation, which was the amount of water below saturation moisture soil content)

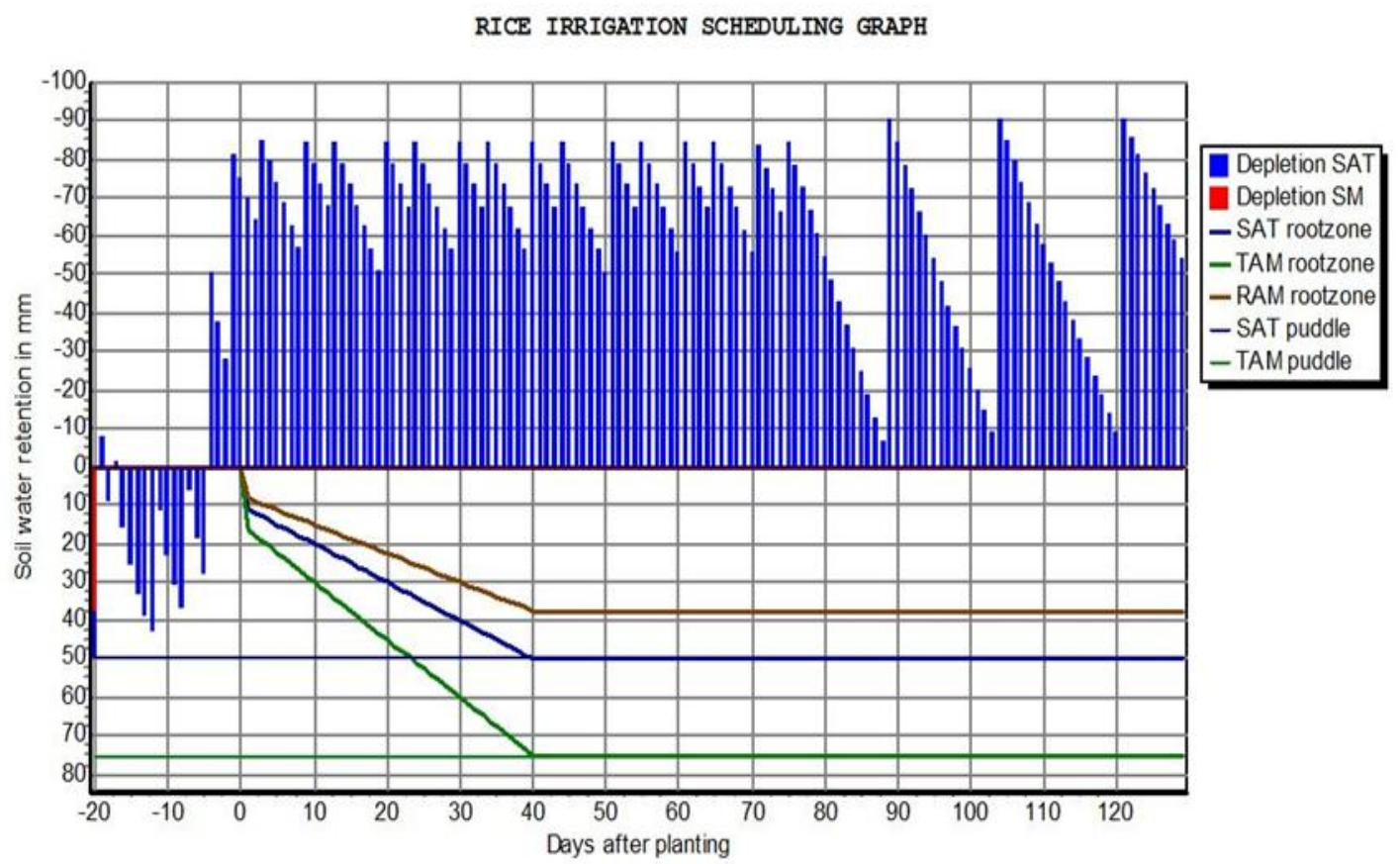


Figure.6 Pictorial representation of irrigation scheduling of wheat

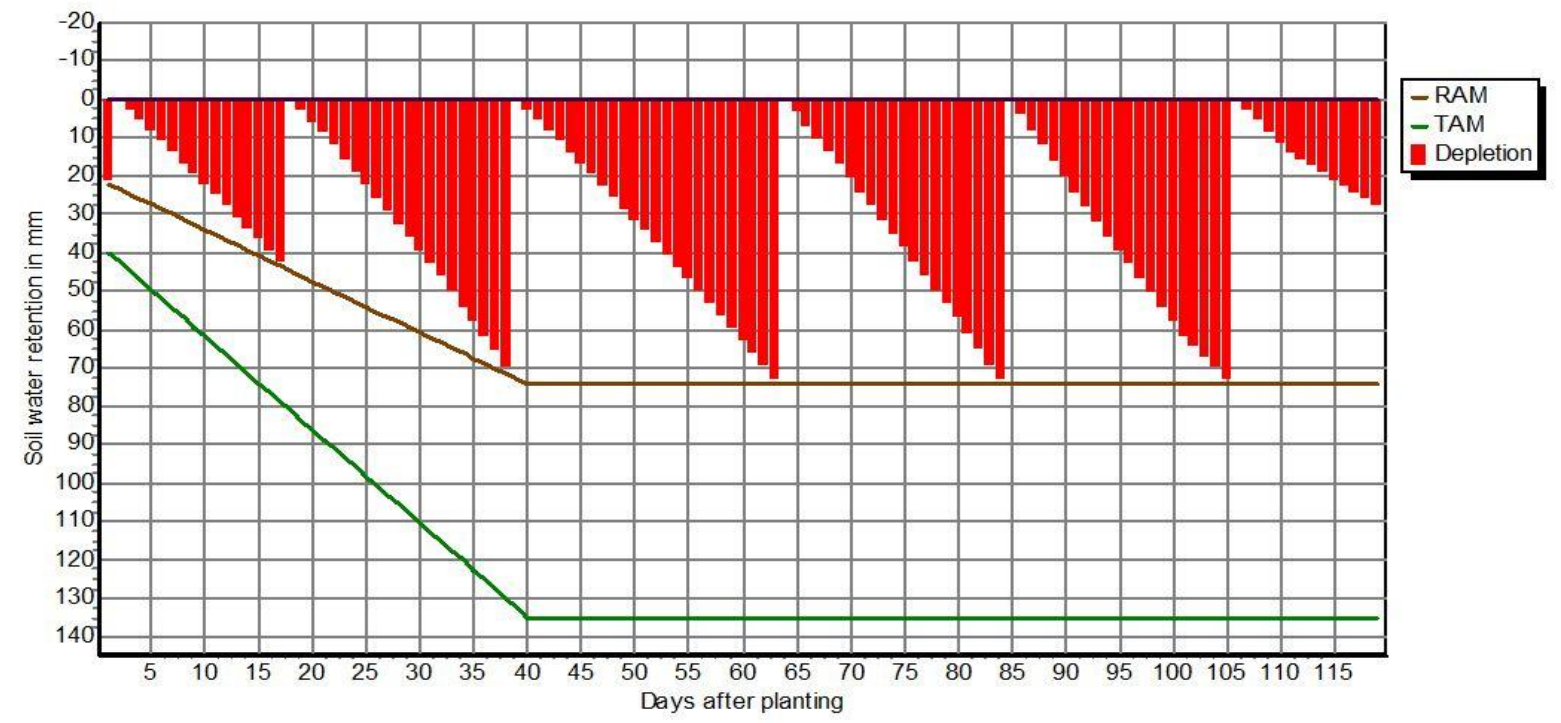

\section{Wheat}

During the crop period of wheat, there was no rainfall. So the irrigation should be provided throughout the crop period. Irrigations is scheduled on $2,18,39,64,85,106$ days after sowing with the net irrigations of $24.1 \mathrm{~mm}$, $45.2 \mathrm{~mm}, 73.6 \mathrm{~mm}, 76.2 \mathrm{~mm}, 77.2 \mathrm{~mm}$, and $75.7 \mathrm{~mm}$ respectively. The gross irrigation for wheat is estimated as $531.4 \mathrm{~mm}$. Irrigation scheduling of wheat is presented in Table 6 . and the respective pictorial representation shown in Figure 6.

From the irrigation scheduling of all the three crops, it is observed that rice and sorghum required less irrigations in rainy season as compared to wheat crops in the non-rainy season. During non-rainy season CWR is to be fulfilled by irrigation only. So the number of irrigations increased, and irrigation may provided according to schedule throughout the crop period and this methodology can be adopt for irrigation scheduling for this particular study area.. From all three crops, the highest water required for rice with 820 $\mathrm{mm}$ without considering the nursery stage.
In conclusions, the reference evapotranspiration, crop water requirement, and irrigation scheduling computed with the help of the CROPWAT 8.0 model is developed by FAO using the crop, soil, and climatic data. The $\mathrm{ET}_{0}$ of study area is directly proportional with solar radiation, and sunshine hours and inversely proportional with relative humidity. The average daily $\mathrm{ET}_{0}$ is found to be $3.25 \mathrm{~mm} /$ day, and it is varied between 5.23 and $1.9 \mathrm{~mm} /$ day. The total average effective rainfall estimated at $527.6 \mathrm{~mm} /$ day, and it is estimated as $58.16 \%$ of the total rainfall. The CWR for sorghum, rice, and wheat are found to be $241.3 \mathrm{~mm}$, $480.9 \mathrm{~mm}$, and $333.9 \mathrm{~mm}$, respectively. The IWR of these crops is estimated by subtracting the effective rainfall from CWR, which is estimated as $188.8 \mathrm{~mm}, 343.3 \mathrm{~mm}$, and $333.9 \mathrm{~mm}$ for sorghum, rice, and wheat, respectively. The net water requirement of sorghum, rice, and wheat is estimated as $157.7 \mathrm{~mm}, 472.8 \mathrm{~mm}$, and $372 \mathrm{~mm}$, respectively. Moreover, the gross water requirement for sorghum, rice, and wheat is obtained as $225.3 \mathrm{~mm}, 502.8 \mathrm{~mm}$, and 531.4 $\mathrm{mm}$, respectively. Thus, CROPWAT can deliver practical guidance to farmers on 
shortfall irrigation scheduling in various crop, soil, rainfall, and climatic conditions.

\section{References}

Alexandratos, N., and Bruinsma, J. (2012). World agriculture towards 2030/2050: the 2012 revision.

Allen, R.G., Pereira, L.S., Raes, D., and Smith, M., $1998 . \quad$ Crop Evapotranspiration-Guidelines for computing crop water requirementsFAO Irrigation and drainage paper 56. FAO, Rome, 300(9), p.D05109.

Allen, R.G., Pereira, L.S., Smith, M., Raes, D., Wright, J.L. FAO-56 dual crop coefficient method for estimating evaporation from soil and application extensions. J. Irrig. Drain. Eng. 2005, 131, 2-13

Biswal, S., \&Rath, A. 2016. Study of Crop Water Requirement of Different Crops in Hirakud Command Area. Int. J. Intelligent Computing and Applied Science, 4(2):42-49.

Bouman BAM, Tuong TP (2001) Field water management to save water and increase its productivity in irrigated lowland rice. Agric Water Manag 49(1):11-30

Capraro, F., Tosetti, S., Rossomando, F., Mut, V., and Vita Serman, F. (2018). Webbased system for the remote monitoring and management of precision irrigation: a case study in an arid region of Argentina. Sensors, 18(11), 3847.

Chitu, Z., Tomei, F., Villani, G., Di Felice, A., Zampelli, G., Paltineanu, I. C., and Costache, R. (2020). Improving Irrigation Scheduling Using MOSES Short-Term Irrigation Forecasts and In Situ Water Resources Measurements on Alluvial Soils of Lower Danube Floodplain, Romania. Water, 12(2), 520.

CROPWAT Software, FAO, Land and Water Division. 2018. Available online: http://www.fao.org/landwater/databases -and-software/cropwat/en/

Ewaid, S. H., Abed, S. A., and Al-Ansari, N. (2019). Crop Water Requirements and Irrigation Schedules for Some Major Crops in Southern Iraq. Water, 11(4), 756.

FAO (Food and Agriculture Organization of the United Nations) (2016) Fertilizer outlook, pp 21-23. http://www.fao.org. Accessed 10 Mar 2017.

Giraldo, P., Benavente, E., ManzanoAgugliaro, F., and Gimenez, E. (2019). Worldwide Research Trends on Wheat and Barley: A Bibliometric Comparative Analysis. Agronomy, 9(7), 352.

IWNI: International Water Management Institute, 2010 Report.

Memon, A.V. and Jamsa, S., 2018. Crop Water Requirement and Irrigation scheduling of Soybean and Tomato crop using CROPWAT 8.0. International Research Journal of Engineering and Technology 5(9): 669-671.

Mundia, C. W., Secchi, S., Akamani, K., and Wang, G. (2019). A Regional Comparison of Factors Affecting Global Sorghum Production: The Case of North America, Asia and Africa's Sahel. Sustainability, 11(7), 2135.

Koech, R., and Langat, P. (2018). Improving Irrigation Water Use Efficiency: A Review of Advances, Challenges and Opportunities in the Australian Context. Water, 10(12), 1771.

Kumari, S., 2017, Irrigation Scheduling Using CROPWAT, International Journal of Creative Research Thoughts (IJCRT), vol 7, issue 12, Page 393-403.

Pereira, L.S., Allen, R.G., Smith, M., Raes, D. Crop evapotranspiration estimation with FAO 56: Past and future. Agric. Water Manag. 2015, 147, 4-20

Sentelhas, P. C., Gillespie, T. J., and Santos, E. A. (2010). Evaluation of FAO 
Penman-Monteith and alternative methods for estimating reference evapotranspiration with missing data in Southern Ontario, Canada. Agricultural Water Management, 97(5), 635-644.

Shah, P.V., Mistry, R.N., Amin, J.B., Parmar A.M., Shaikh, Moh. R.A. 2015. Irrigation Scheduling Using CROPWAT. International Journal of Advance Research in Engineering, Science and Technology (IJAREST), 2 (4), pp 1-10.

Singh, R., Singh, K., and Bhandarkar, D. M. 2014. Estimation of water requirement for soybean (Glycine max) and wheat (Triticum aestivum) under vertisols of Madhya Pradesh. Indian J Agr Sci, 84, 190-197.

Smith, M. (1991). CROPWAT: Manual and guidelines." FAO of UN, Rome.

Smith, M., Allen, R., and Pereira, L. (1998). Revised FAO methodology for crop-water requirements (No. IAEATECDOC--1026).

United Nations, Department of Economic and Social Affairs, Population Division (2019). World Population Prospects 2019: Highlights (ST/ESA/SER.A/423).

\section{How to cite this article:}

Khose Suyog Balasaheb and Sudarsan Biswal. 2020. Study of Crop Evapotranspiration and Irrigation Scheduling of Different Crops Using Cropwat Model in Waghodia Region, India. Int.J.Curr.Microbiol.App.Sci. 9(05): 3208-3220. doi: https://doi.org/10.20546/ijcmas.2020.905.381 